Whitley Stokes, On the assimilation of pretonic $n$.etc. 167

not been already discussed are mulier, and baliolus, neither of which are of certain derivation. If mulier really is a com-

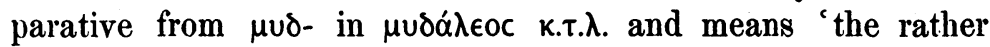
moist', or 'the more moist creature' i. e. (!) 'she who gives suck', it must have been taken up, like miles as a slang word from the language of the commonest people, which would account for its regular contemptuous sense in Latin. baliolus is applied to an 'Afer' in Plautus and is certainly more likely to mean 'dusky' (badius) than 'dappled' (Bódıoc). If it is the former it might be classed with caesius, rufus, as a borrowed word, restricted to the meaning of a personal epithet.

Cambridge, England Dec. 19. 1891.

R. Seymour Conway.

\title{
On the assimilation of pretonic $n$ in Celtic suffixes.
}

"Ferner scheint $n$ als Anlaut hochbetonter $n$-Suffixe an die Nachkommen idg. wurzelschliessenden Verschlusslaute assimiliert worden $\mathrm{zu}$ sein. So lässt sich die urgerm. Konsonantendehnung erklären z. B. ahd. lecchōn 'lecken', urgerm.

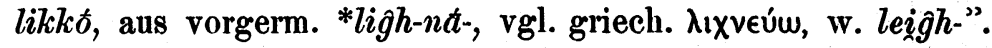
Grundriss I § 214.

" $b n, d n, g n$ vor dem Hauptton wurden im Urgerm. zu $b b, d d, g g$, daraus nach $\$ 533 p p, t t$, $k k$, die weiter ebenso behandelt wurden, wie die aus idg. $p n, t n, \hat{k} n, q n$ und ans idg. bhn, $d h n, g h n, g h n$ entstandenen $p p, t t, k k(\$ 530.538) "$. Grundriss I \& 534 ${ }^{1}$ ).

Though well aware of the danger of assuming that a phonetic law, good for one family of languages, is good for another, it seemed to me, when I read these passages, that they gave the key to the etymology of six groups of Celtic words, which have not, so far as I know, hitherto been explained. I mentioned this key, briefly, in KZ. XXIX 375, and now after five years' consideration, I proceed to submit to Celtologues the words in question and their respective etymologies.

1) Cf. Paul-Braunes Beiträge VII 1332, Osthoff ibd. VIII $297 \mathrm{ff}$. Kluge ibd. IX 149 ff. Kauffmann ibd. XII 504 ff. 
I. $g g$ from -gná, -gni, -gnó, -gnó.

1. Ir. acus, ocuis 'und', urkelt. *akkusti, aggústi, vorkelt. *aghnústi, cognate with Lat. angustus, Gr. äxvvual, (Schmidt Vokalismus I 31), äryı. So Cymr. ach 'near', urkelt. *akki, *aggi, vorkelt. *aghni.

2. Gaul. bräca 'die Hose', urkelt. *bräkkā from *bräggáa (the provection being due to the accent). Vorkelt. *bhräg-ná derived from bhräg 'Steiss'. Cognate with Lat. frägum, fräg-ro. For the connexion of ideas compare Lith. bulis 'Hinterback', Skr. buli 'vulva', cognate with Ir. bolad (urkelt. *bulato-s) 'Geruch'; Skr. puta m. du. 'die Hinterbacken', BR., cognate with püy, püyate estinken' : Lat. podex cognate with pedo :

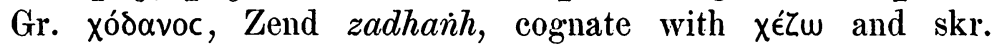
had. From the Gaulish braca (where the urkelt. $k k$ is simplified) are borrowed, on the one hand, Romanic words like Ital. braca, O.Fr. braie, and, on the other, Teutonic words, such as OHG. pruoh, ON. brókr, Ags. bróc pl. bréc, Eng. breech 'Steiss'.

3. Gaulish clocca 'Glocke', Cymr. cloch F. Urkelt. *klokka from an oxyton $* k \log a \dot{a}$. Vorkelt. *klog-náa cognate with

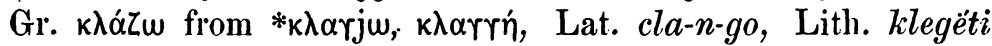
'to laugh', ON. hlakka 'to scream'. The Irish cognate is clocc, a masc. $o$-stem, deducible from a vorkelt. ${ }^{*} k \log$-nó-s.

4. Ir. fecc 'Spaten'. Urkelt. *vekka, *veggá. Vorkelt. *vegh-ná. Cognate with Lat. va-n-ga, Gr. opvíc, Pruss. wagnis 'coulter'.

5. Ir. aicc, aic, 'Band, Kette'. Urkelt. *akki, *aggí, vorkelt. *pag-ni (the loss of the $p$ is regular). Cognate with Lat. pa-n-go, Gr. $\pi \eta \dot{\gamma}-v u-\mu$. From aicc is derived Ir. aicde 'a building'.

6. Cymr. crych 'gekräuselt', Bret. crech. Urkelt. *krekko-s, *kreggó-s. Vorkelt. *kregh-nó-s. Cognate with Ags. hring, ON. hringa, O.Slov. kragb 'Kreis', kragls 'rund'.

7. Ir. licc in álic $\left(=\right.$ ad-lic) and adlaic $\left.{ }^{1}\right)(=$ aithlic) 'angenehm, gefallend', Cymr. lip in cyffelyb 'consimilis'. Urkelt. *liqqi-, *liggi, vorkelt. *lig-ni. Cognate with Goth. galeiks, leikan, Lit. lygus, Skr. linga-m (J. Schmidt Vokalismus I 89).

1) corruptly adhailg, $\mathrm{O}^{\prime} \mathrm{Cl}$. 
8. Ir. menicc 'häufig, reichlich, oft', Cymr. mynych. Urkelt. *menekki-, *meneggi. Vorkelt. *menegh-ní. Cognate with got. manags 'viel', aslov. mznogz (Kluge s. v. manch).

9. Ir. tricc 'schnell', urkelt. *trekki-s, *treggi-s, vorkelt.

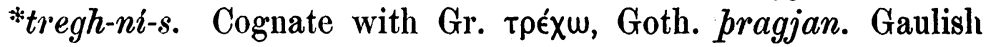

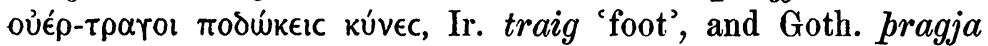
exhibit a different grade of vowel.

10. Ir. bacc 'Krummstab, Haken', cymr. bâch 'hamus, uncus'. Urkelt. *bakko-, *baggó-, vorkelt. *bhag-nó-. Cognate with Ags. bcec, Eng. back, Skr. Vbhaj 'sich wenden'. For the connexion of ideas compare NHG. Rücken cognate with Skr. $\checkmark$ kruñc 'sich krümmen'.

11. Ir. bocc 'zart', bocc 'Bogen' (in fid-bocc 'arcus ligneus'), urkelt. *bukko-, *buggó-. Vorkelt. *bhug-no-. Cognate with Ags. boga, NHG. Bogen, biegen, biegsam, Gr. 甲єúrw, Lat. fugio. Skr. لbhuj, part. perf. pass. bhugna.

12. Ir. bocc 'Bock', Cymr. bwch M., urkelt. *bukko-s *buggó-s, vorkelt. *bhug-nó-s. Cognate with Zend büza 'Bock', Ags. bucca, ON. bukkr, OHG. boc.

13. Ir. brecc 'bunt, gefleckt', Cymr. brych, urkelt. *mrekko-s, *mreggós, vorkelt. ${ }^{*} m r e g-n \delta$-s. Cognate with Lit. margas. Another participle from the same root is 0.Ir. mrecht, Cymr. brith, urkelt. ${ }^{*}$ mrektos $={ }^{*}$ mreg-to-s.

14. Ir. 'cnocc M. 'Hugel', O.Bret. cnoch (gl. tumulus), urkelt. *knokko-s, *knoggó-s, vorkelt. *knog-nó-s. Cognate with ON. hnakke 'Hinterhaupt', Ags. hnëcca, Eng. neck, NHG. Nacken, see Kluge s. v. Nacken. In Cymr. cnwc, pl. cnyciau 'gibbus, tuber', we have an unexplained preservation of the urkelt. $k k$.

15. Ir. lacc, lac 'schwach', urkelt. *lakko-s, *laggó-s, Vorkelt. *lag-nós. Cognate with lat. la-n-guidus, griech. $\lambda \alpha-$

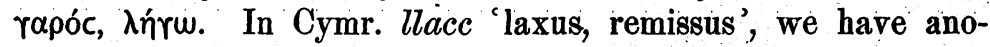
ther instance of the preservation of urkelt. $k k$.

16. Ir. *lecc "leac an act or deed which binds the persons indissolubly", O'Don. Supp. Urkelt. *likka (-ko-?), *ligga (-gó-?). Vorkelt. *lig-ná (-nó-?). Cognate with Lat. ligare, ligula.

17. sluccim 'ich schlucke ein, verschlucke'. Urkelt. *slukkō *sluggó, vorkelt. *slug-nó. Cognate with Gr. $\lambda u ́ l \omega$

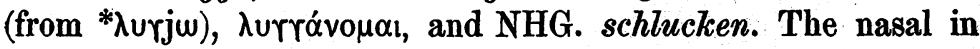


the corresponding British verbs - Cymr. llyngcu 'deglutire, gurgitare', O.Bret. ro-luncas (gl. guturicauit) seems due to a contamination of the regular luch .. with the urbritt. equivalent of the Ir. longud 'essen' (Cymr. llewa 'edere, manducare'); or of the Goth. fra-slindan 'verschlingen'.

II. $d d$ from $-d n \dot{a},-d n i,-d n o ́,-d n o ́,-d n o ̄ n$.

18. Ir. cit 'Schaf', whence citen, cetnait 'Lamm'. Urkelt. *ketti-, *keddi-. Vorkelt. *ked-ni-. Cognate with urgerm. *hadna 'Ziege', Fick's Wörterb. ${ }^{3}$ III 61.

19. Ir. gataim 'ich nehme weg, erbeute, stehle'. Urkelt. *gattō, *gaddó, vorkelt. *ghadh-nó-. Cognate with Skr. $\checkmark$ gadh (Strachan), Vedic gadhia 'was zu erbeuten ist' (Grassmann). Kıccóc from * $*_{\kappa} \theta$ jóc and Lat. hederā have also been referred to $/ g h a d h$. The idg. root ghad, whence Gr. $\chi \alpha v$ ¿ávw Lat. pre-hendo, Goth. bi-gitan, is represented in Celtic by Cymr. 'genni contineri, comprehendi, capi'.

20. Ir. *gett, now gead 'Steiss', whence geadán 'buttock', O’Don. Supp. Urkelt. *getto-, *geddó-, vorkelt. *ghed-nó-. Cog-

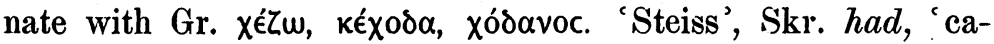
care', zend zadhanh 'podex'.

21. lútu 'der kleine Finger', gen. lútan, dat. lútain, urkelt. *lüttōn, gen. *lūttenos, *lüddón. Urkelt. *lüd-nón. Cognate with Ag:s. lytel, OHG. luzil.

22. *rataim 'ich gebe', do-rata 'det', do-ratus 'dedi'. Urkelt. *rattô, "raddᄒ. Vorkelt. *radh-no' ${ }^{*}$ ). Cognate is Skr. $\checkmark$ radh, randh 'uberliefern, in die Gewalt geben'. See Schmidt Vocalismus I 36. From the unnasalised form of the root comes the M.Cymr. perfect dyrodes, where the ending of the $s$-pret. is added to the perfect rod. This rod (= old Welsh

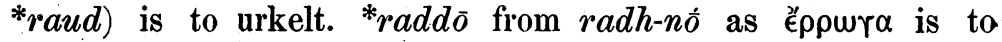

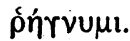

23. Ir. sláet, 'Schleifbahn, Gleitbahn', LL. $301^{\text {a }} 7$. Urkelt. *slaitto, *slaiddó, vorkelt. *slaidh-nó-. Cognate are Lith. slidus 'glatt', Ags. slidan, NHG. Schlitten, Skr. sridh 'straucheln, fehlgehen'.

1) Windisch Wörterb. 499, brings doubtfully Ir. rat from rodad, Skr. dadämi. But in Old Celtic the verb corresponding with

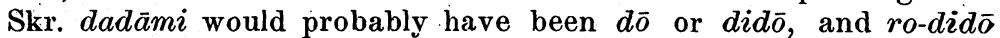
would have yielded ro-diud in Irish. 
24. Ir. tot = tonn 'a wave', O'Cl. Urkelt. *tutta, *tuddá. Vorkelt. *tud-ná. Cognate are Skr. tudāmi 'ich stosse', Lat. tudes, tuditare, Goth. stauta. In Ir. and Cymr. tonn 'wave', urkelt. ${ }^{*}$ tunda $\bar{a}$, the root is nasalised as in Lat. tundo, Pertunda, Skr. tundate.

\section{III. $b b$ from $-b n i,-b n \delta,-b n u$.}

25. Ir. scip 'hand', dat. sg. ina dag-scip, LB. $240^{\mathrm{a}}$. Urkelt. *skeppi-, *skebbi-. Vorkelt. *skeb-ni. Cognate are Goth. ga-skapjan, Eng. shape, NHG. schaffen. In Ir. ceaptha 'shapen', 'brought into form', O'Don. Supp. we have a part. pret. pass. from a sister-root $k e b$.

26. Ir. gop M. 'Mund, Schnabel, Schnauze', compd. gopchúil, LU. $122^{\text {a }}$ 35. Urkelt. *goppo-s, *gobbó-s. Vorkelt.

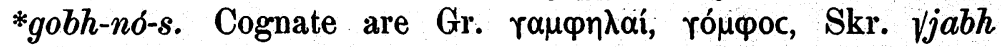
'schnappen', jambha 'Zahn', O.Sl. zobiti 'essen'.

27. rap 'every animal that drags to it, ut sunt sues', Corm. Urkelt. *rappo-, rabbó-, vorkelt. *rab-nó-. Cognate with NLG. rapen 'zusammenraffen', NHG. raffen. Or O.Bulg. rabiti secare, rapere?

28. Old-Ir. *bapp, *bopp 'Buischel, Quast', M.Ir. papp, popp, Highland Gaelic bab M., gen. baba. Urkelt. *bappu-, *bobbu-, *babbui-, *bobbú-. Vorkelt. *babh-nú, *bhobh-nú. Cognate with Lat. $f a b a^{1}$ ), haba, Pruss. babo, O.Slav. bobz, and

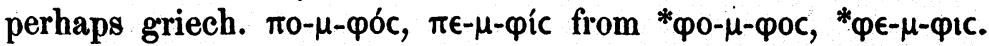
The Eng. bob 'bunch, knob, plummet' seems either borrowed from or cognate with 0.Ir. bopp. The initial $p$ in M.Ir. popp LU. $97^{\text {a }} 3$, pl. acc. pupu LB. $127^{\text {a }}$ may be due to assimilation, as in M.Ir. prapad = 0.Ir. brafad, urkelt. "qenqi 'funf" $=$ vorkelt. *penqi, and Eng. Bob a pet-form of Robert.

Other words, such as Ir. croccenn 'Haut', di-bracim 'ich werfe, schiesse', fracc 'Hand', frace or fraicc 'Schild', glice 'klug', fuit 'Kälte', cuit 'Teil', grut 'Quark', slat (cymr. llath) 'Ruthe', lott 'Hure', cepoc 'Chorgesang', lapp 'Schlamm', opunn, t-opp 'plötzlich': (cf. ỏ' Steiss' (cf. Skr. stambha), and Cymr. gwych 'brav', mellt 'Blitze', cloff 'lahm', lleibio 'lecken' (bret. lippat) may possibly be explained in like manner. But enough has been said

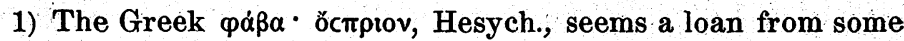
Sicilian dialect closely related to Latin. 
to make it probable, if not to prove, that in Ur-celtic, as in Ur-germanic, the initial $n$ of the accented $n$-suffixes was sometimes assimilated to a preceding $g, d$ or $b$. We have now to notice some instances where the same $n$ appears to have been assimilated to a preceding $k, t$, or $p$.

IV. kk from kná, knó-, knón-, knú-.

29. Cymr. ach F. 'generation', achen 'lineage', O.Cymr. achmonou (gl. inguinibus), Ir. aicme 'genus', aicned 'natura'. All from an urkelt. *akkā, vorkelt. *akná. Cognate with Skr. åka 'Bug, Seite, Schooss' and äkna, vy-akna, sam-akna 'gebogen' Fick ${ }^{3}$ i. 6.

30. Ir. lecc F. = cymr. Ilech 'tabula saxea'. Urkelt. *lekka or *lkka, vorkelt. *plk-ná. Cognate with Lat. planca, placenta. Gr. $\pi \lambda \alpha \dot{\xi}, \pi \lambda \alpha \kappa o \hat{c}$, nhg. flach.

31. Ir. lecco 'Wange', gen. leccon, urkelt. *lekkōn, vorkelt. *lek-nón. Cognate with O.Pruss. laygnan for *layknan,

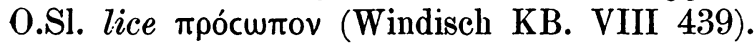

32. Ir. sicc now siocc 'Frost', urkelt. 'sikku, vorkelt. *siq-nú. Cognate with Lat. siccare. Skr. sikata, Zend hikuš (Bartholomae KZ. XXIX 525).

33. Cymr. trînch 1. fractus, mancus, mutilus. 2. scissura incisio, incile. Urkelt. *trokko-s. Vorkelt. *trok-nó-s. Cognate with Lat. tro-n-cus, truncus, Lith. 'trinka 'Block, Klotz'.

34. Old-bret. *techam 'ich fliehe', M.Bret. infin. techet 'fugere, urkelt. *tekkô-, vorkelt. *tek-nt. Cognate with Lith. tekinas 'laufend, schnell' So the Irish techim 'I flee' is cognate with Lith. teku, teketi 'laufen, fliessen', Zend W\%. tac 'laufen, eilen, fliessen'.

In the same way, perhaps, may be explained Ir. béccim 'ich briulle, blöke', (Cymr. beichio 'mugire'): Ir. fo-thrucud 'Bad' = M.Bret. gou-zronquet (Cymr. trochi 'mergere, balneare') : Ir. cocca 'Boot' (Cymr. cwch), Ir. mucc 'Schwein' (Cymr. moch) : Ir. icc 'Heilung' (Cymr. iach), cace 'Koth', (Cymr. câch), Ir. grác 'Gekrächze' cf. Lat. gräculus).

$$
\text { V. } t t \text { from -tná, -tnó. }
$$

35. Ir. bratt M. 'Mantel', Cymr. map-brethinnou (gl. in cunis), urkelt. *bratto-s, vorkelt. *brath-nó-s, *grath-nó-s. Cognate with Ir. bréit 'ein Streifen Wollenzeug', which Rhŷs has brought from *branti $=$ skr. granthi 'tie, knot'. 
36. Ir. crett F. 1. 'Körper', 2. 'Wagenkasten', urkelt. *krtta,

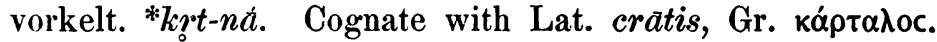

37. Ir. lat i. troigh, 'Fuss', O'Cl. Urkelt. *lattā (latto-?), vorkelt. *plat-ná (nó-?). Cognate with Lat. planta 'Fusssohle', Gr. $\pi \lambda \alpha \tau u ́ c$, Lith. platìs.

38. Ir. littiu, gen. litten, Cymr. llith 'Mehlsuppe'. Derived from an urkelt. *ltto-, vorkelt. *plt-nó-. Cognate with

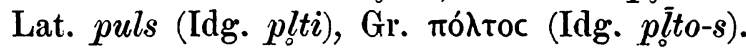

In like manner we may explain Ir. mut 'kurz', cognate with Lat. mutilus.

\section{VI. $p p$ from -pnó, -pni.}

39. Ir. cep M. 'a piece of ground', whence Mod.Ir. ceapach 'a piece of ground laid out for tillage', O'Don. Supp. Urkelt. *keppo-s, vorkelt. *kep-nó-s. Cognate with Lat. ca-mpus, Lith. kampas 'Winkel, Ecke, Gegend', Pol. kepa 'Flussinsel' Dor. kâmoc.

40. Cymr. craff 'firmus', urkelt. *krappo-s, vorkelt. *krap-nó-s. Cognate with O.Slav. krèpz 'fortis', ON. hroefa 'ertragen', kr’afr, kv'äptr 'robur' (Ebel KB. II 174, Schmidt Vokalismus II 72).

41. Ir. crip 'schnell', urkelt. *krppi, vorkelt. *krp-ni.

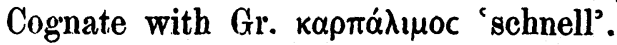

42. Ir. ropp M. 'ein stössiges Thier', 'every animal' that gores, ut sunt uaccae', Corm. urkelt. *ruppo-s, vorkelt. *rup-nó-s. Cognate with Lat. ru-m-po, Goth. bi-raubōn, Ags. recifian, reofian, $0 \mathrm{~N}$. rjúfa.

43. 0.Ir. *répaim, Mid. and Mod. Ir. rébaim, reubaim 'ich reisse, zerreisse', urkelt. *reippo, vorkelt. *reip-nó. Cognate is Ir. rép in the compound rép-gaeth 'reissender Wind" LL. $83^{a} 51$. Teutonic cognates are $\mathrm{ON}$. rifna 'to be rent, riven, cracked', Vigf., rifa 'a rift' Eng. to rive.

Of the above etymologies, eight, namely those numbered $5,9,12,13,21,31,32,35$, are due to Professor Strachan, who also pointed out to me that the Ir. adj. bocc 'soft' (No. 11) might he deduced from bhugno-: that 2. gataim (No. 19) might be connected with the Skr. Vgadh; and that bulis and buli were cognate with Ir. bolad (No. 2).

Whitley Stokes. 